\title{
透過波長域が異なる近紫外線除去フィルムと 透過フィルム下で軟弱野菜の害虫類が示す行動反応
}

\author{
太田 泉・武田光能・本多健一郎 \\ Izumi Ohta, Mitsuyoshi Takeda and Ken-ichiro Honda: Behavioral responses of insect pests attacking \\ leaf vegetables under ultraviolet-absorbing plastic films with different wavelengths transmitted and \\ ultraviolet-transmitting films
}

\begin{abstract}
Summary
The movement of five leaf vegetable insect pests, Athalia rosae ruficornis, Phyllotreta striolata, Plutella xylostella, Chromatomyia horticola and Thrips tabaci were examined with an ultraviolet (UV)-transmitting plastic film and four UV-absorbing films, which blocked wavelengths below $340 \mathrm{~nm}, 360 \mathrm{~nm}, 370 \mathrm{~nm}$ or $380 \mathrm{~nm}$. The insects were placed in an experimental box covered with the UV-transmitting film and the UV-absorbing film; their choice behaviors were observed. The numbers of $A$. rosae, P. striolata and T. tabaci distributing in the area under all the UV-absorbing films tested were smaller than those under the UV-transmitting films. Movement of P. exlostella and C. horticola into areas under films blocking UV wavelengths below $360 \mathrm{~nm}$, $370 \mathrm{~nm}$ and $380 \mathrm{~nm}$ was suppressed compared to that with the UV-transmitting films. From these findings, we would expect the five insect pests tested to avoid light conditions that do not contain UV wavelengths of $360 \mathrm{~nm}$ and less.
\end{abstract}

\section{緒言}

大消費地に隣接する都市近郊では，多種多品目の野菜 類が集約的に栽培されている。特にビニールハウス等の 施設では，コマツナ，ホウレンソウなどの軟弱野菜類の 周年生産が盛んに行われている。軟弱野菜類には多くの 害虫が発生し，その食害は商品価值の著しい低下や減収 を引き起こす。しかし，軟弱野菜類では，使用可能な登 録殺虫剂が他の野菜類と比較して少ない ${ }^{1)}$ 。また, 2006 年 5 月のポジティブリスト制度の施行により，散布した 農薬の近接ほ場への飛散防止が強く求められている そのため, 軟弱野菜類では, 農薬に依存しない害虫防除 技術の開発が求められている。現在までに，防虫網被覆 や太陽熱消毒, 害虫捕虫機などの様々な物理的防除法が 試みられ，有用な結果が報告されている

近紫外線除去フィルムは, 1970年代に開発された物理 的防除資材で，当該フィルムを被覆した施設内では近紫 外線（UV-A，波長 315〜400 nm）が除去された光環境 となる。現在まで, アザミウマ類やアブラムシ類, コナ ジラミ類，ハモグリバエ類に対しての防除効果が知られ
ており ${ }^{5,6)}$ ，おもに果菜類の施設栽培で利用されている。 しかし, 軟弱野菜類栽培への近紫外線除去フィルムの使 用事例はあまり知られていない。

そこで, 著者らは, 軟弱野菜類で多く発生するカブラ ハバチ，キスジノミハムシ，コナガ，ナモグリバエ，ネ ギアザミウマに対する近紫外線除去フィルムの防除効果 を調べるため, フィルムを透過した光に対する害虫の行 動反応を解析する実験装置を作製して, 透過波長域が異 なる近紫外線除去フィルムの各害虫の行動に与える影響 を明らかにした。なお, 本研究で用いた近紫外線除去フィ ルムは, MKV プラテック株式会社開発研究所より提供 されたものである。ここに記して感謝申し上げる。

\section{材料および方法}

1.フィルム

近紫外線域の透過波長が異なる 4 種類のポリオレフィ ン系フィルム (厚さ $0.15 \mathrm{~mm}$ ) を供試した。透過率が $1 \%$ 未満になる波長域は, (a) のフィルムが $340 \mathrm{~nm}$ 以下, (b) が $358 \mathrm{~nm}$ 以下，（c）が $366 \mathrm{~nm}$ 以下，（d）が $383 \mathrm{~nm}$ 以 


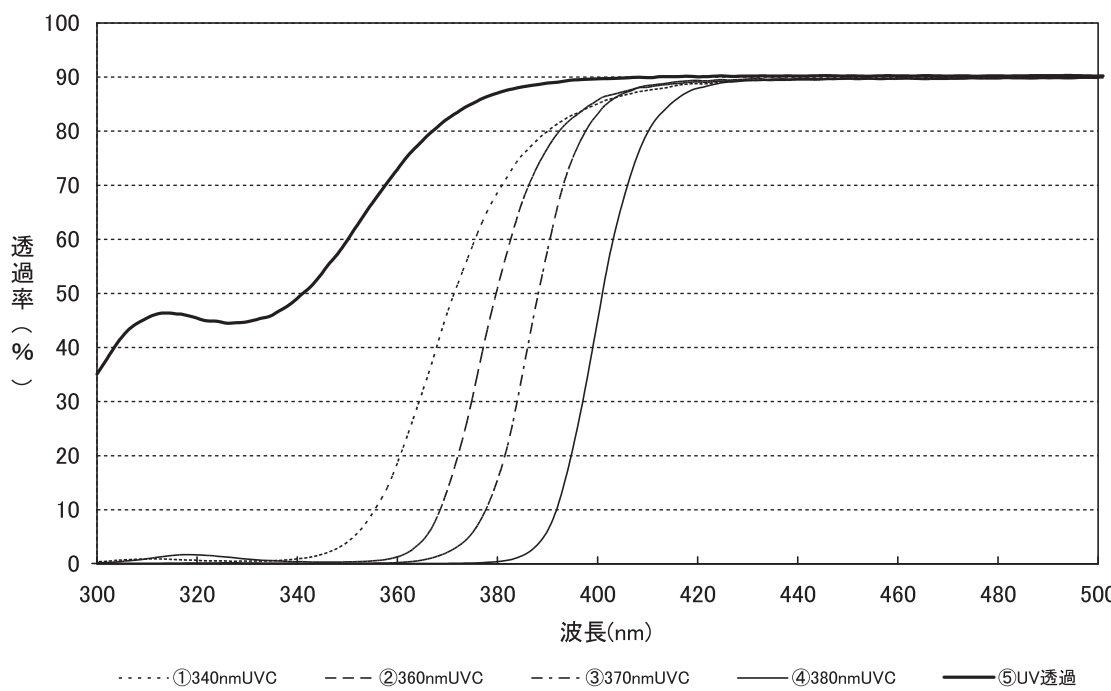

第 1 図 供試した近紫外線除去フィルム 4 種類と透過フィルムの波長別の透過率 （データは MKV プラテック株式会社開発研究所からの提供）

下であるため（第 1 㘠），以後（a）を $340 \mathrm{~nm} \mathrm{UVC，（b）}$ を $360 \mathrm{~nm} \mathrm{UVC，（c）を} 370 \mathrm{~nm} \mathrm{UVC，（d）を} 380 \mathrm{~nm}$ UVCフィルムと称した。なお，対照として，近紫外線 を透過するポリオレフィン系フィルム（アグリスター ${ }^{\circledR}$ $0.1 \mathrm{~mm}$ 厚， MKV プラテック製）を用いた（以後，透過 フィルムと称する)。

\section{2。供試虫}

本試験には, 軟弱野菜類を加害するカブラハバチ Athalia rosae ruficornis Jakovlev, キスジノミハムシ Phyllotreta striolata (Fabricius), コナガ Plutella xylostella (Linnaeus), ナモグリバエ Chromatomyia horticola (Goureau), ネギアザウマ Thrips tabaci Lindeman の害虫 5 種を供試 した。カブラハバチは，2008年 9 月に三重県津市のコマ ツナから老熟幼虫を採集し，温度約 $25^{\circ} \mathrm{C}$ ・日長 $14 \mathrm{~L} 10 \mathrm{D}$ に調節した恒温室内でコマツナ（ポット植え）を与えて 累代飼育した。試験には羽化 1 週間以内の雌成虫を用い た。キスジノミハムシは，2007年 8，9月に三重県津市 のコマツナから採集された成虫を試験に用いた。コナガ は，2004年 4 ～ 8 月に三重県津市のキャベツから成虫を 採集し, 温度約 $20^{\circ} \mathrm{C}$ ・日長 $16 \mathrm{~L} 8 \mathrm{D}$ に調節した恒温室内 でカイワレダイコン種子の芽出しを与えて累代飼育し た。試験には羽化 1 週間以内の雌成虫を用いた。ナモグ リバエは，2006年 2 月に神奈川県三浦市のダイコンから 蛹を採集し，温度約 $20^{\circ} \mathrm{C} ・$ 日長14L10D に調節した恒温 室内でダイコン（ポット植え）を与えて累代飼育した。 試験には羽化 1 週間以内の成虫を用いた。ネギアザミウ マは，2007年 7 月に三重県津市のコマツナから成虫を採 集し, 温度約 $20^{\circ} \mathrm{C}$ ・日長14L10D に調節した恒温室内で コマツナ（ポット植え）を与えて累代飼育した。試験に
は羽化 1 週間以内の成虫を用いた。

\section{3. 実験装置}

鹿島・松井 ${ }^{7)}$ の方法を参考にして，近紫外線除去フィ ルムと透過フィルムの透過光に対する害虫の選択行動を 観察するための実験装置 2 種類（角筒タイプ，円筒タイ プ；どちらも筒を横置きにして使用）を作製した。角筒
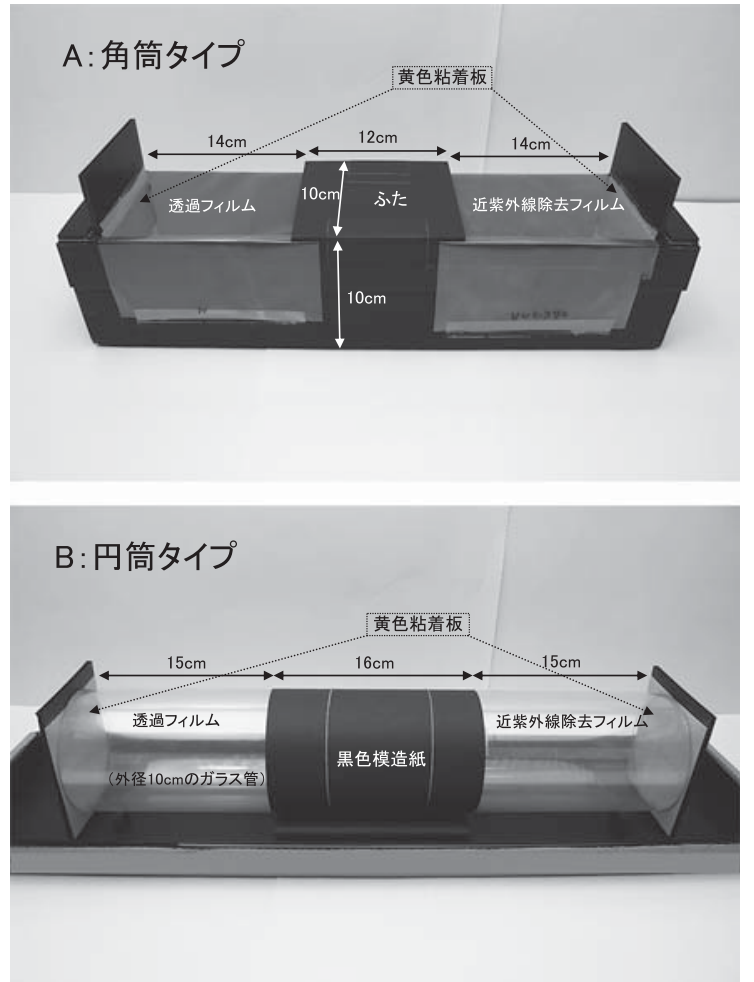

第 2 図 近紫外線除去フィルムと透過フィルムの透過光に対す る害虫の選択行動反応を観察するための実験装置 (A : 角筒タイプ, B : 円筒タイプ) 
タイプは, 厚さ $4 \mathrm{~mm}$ の黒色プラスチック板を加工した もので, 左右の上側が開口した箱状（断面 $10 \times 10 \mathrm{~cm}$, 長さ $45 \mathrm{~cm}$ ）の構造である（第 2 図 A)。装置両端に黄 色粘着板（ホリバー ${ }^{\circledR}$ 黄色，アリスタライフサイエンス 製)，左右上側の開口部分（長さ $14 \mathrm{~cm} ）$ にそれぞれ近 紫外線除去フィルムと透過フィルムを取り付けた。中央 部分（長さ $12 \mathrm{~cm} ）$ には本体と同素材のふたを被せた。

微小な空隙から逃亡しやすいキスジノミハムシとネギ アザミウマには，より密閉性の高い円筒タイプの実験 装置を作製した。本装置は, 直径 $10 \mathrm{~cm}$, 肉厚 $2.4 \mathrm{~mm}$, 長さ $47 \mathrm{~cm}$ のガラス円筒管からなり，両側（長さ 16 $\mathrm{cm}$ ）を近紫外線除去フィルムと透過フィルムで，中央 （長さ $15 \mathrm{~cm}$ ）を黒模造紙で被覆した（第 2 図 B）。両端 には $10 \mathrm{~cm}$ 角の黄色粘着板（同上）を取り付けた。

4. 近紫外線除去フィルムと透過フィルムの透過光に対 する供試虫の選択行動

試験は, 陽光定温器（小澤製作所 G4 改良型, 内寸 : 幅 $100 \mathrm{~cm}$ ×奥行き $85 \mathrm{~cm}$ ×高さ $75 \mathrm{~cm}$ ）内で行われた。 定温器の内部は温度 $25 \sim 30^{\circ} \mathrm{C}$ 調整し, 上面には東芝・ 陽光ランプ D250F とパナソニック・マルチハロゲン灯 MF400・S/VH をそれぞれ 4 本ずつ, 左右側面には東芝・ ブラックライト蛍光灯 FL20S・BLB-A を 6 本ずつ取り 付けて, 内部を照明した。近紫外線除去フィルムと透過 フィルムを装着した実験装置を定温器内部の中央に置 き，装置内部と直上の照度，紫外線強度，温度，相対湿 度を測定した。照度の測定にはミノルタ $\mathrm{T}-1$, 紫外線強 度はトプコン UVR-2（受光部 UD-36 : 測定波長域 310$400 \mathrm{~nm})$, 温湿度はティアンドディ TR-72U を使用した。

炭酸ガスで麻酔した所定数の供試虫を実験装置内の中 央暗部に放して 1 時間静置した。カブラハバチは雌成虫 30頭, コナガは雌成虫50頭, キスジノミハムシとナモグ リバエは成虫50頭，ネギアザミウマは成虫 100 頭を供試 した。試験終了時に, フィルムで被覆された部分（黄色 粘着板を含む）に静止している害虫の数を記録した。1 つの試験につき装置の左右を交互に変えて合計 4 反復を 行い, 反復ごとに新しい虫を使用した。供試虫がフィル ムの透過光の影響を受けずに実験装置内でランダムに移 動した場合，紫外線除去フィルム部分と透過フィルム部 分に分布する虫の頭数比は $1 ： 1$ と仮定される。両フィ ルム部分へ移動した害虫の頭数比のデータは, 反復間 で有意な差がないことを確認した上で 4 反復分を合計 し, 比率 1 ：1 に対する適合性検定 (Heterogeneity chisqaure analysis ${ }^{11)}$ ) を行った。
結果

近紫外線除去フィルムと透過フィルムの透過光に対す る供試虫 5 種の選択行動反応を第 $3,4,5,6,7$ 図に

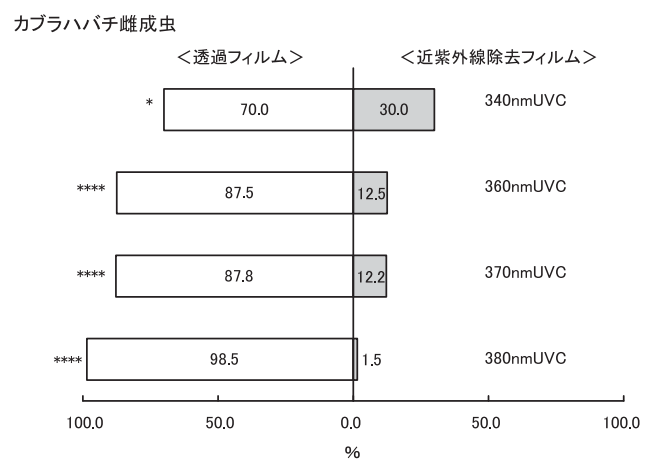

第 3 図透過波長域が異なる近紫外線除去フィルムと透過フィ ルム下でのカブラハバチ雌成虫の分布状況（角筒タイ プ)

$*\left(0.01<p<0.05\right.$, Heterogeneity chi-square analysis $\left.{ }^{11}\right)$, $* * * *(p<0.001$, 同上)

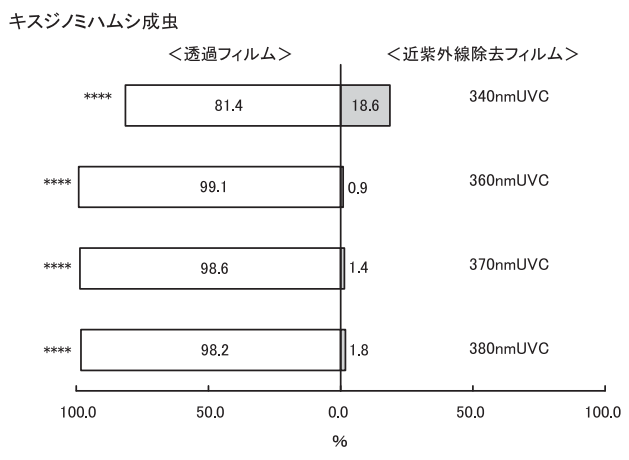

第4図 透過波長域が異なる近紫外線除去フィルムと透過フィ ルム下でのキスジノミハムシ成虫の分布状況（円筒夕 イプ)

**** $\left(p<0.001\right.$, Heterogeneity chi-square analysis $\left.{ }^{11}\right)$

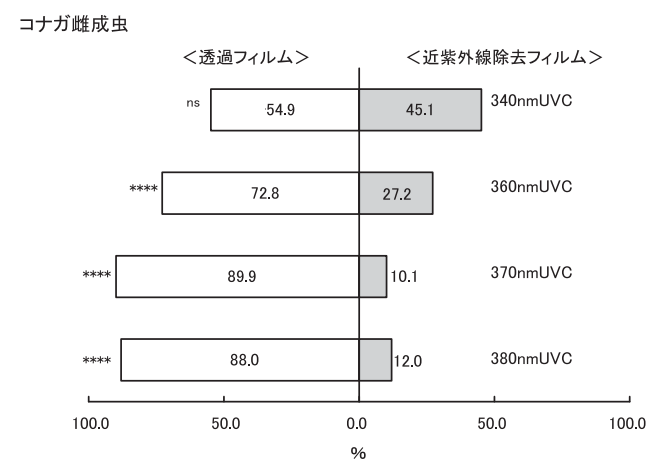

第 5 図 透過波長域が異なる近紫外線除去フィルムと透過フィ ルム下でのコナガ雌成虫の分布状況（角筒タイプ） ns $\left(p>0.05\right.$, Heterogeneity chi-square analysis $\left.{ }^{11)}\right)$, $* * * *(p<0.001$, 同上 $)$ 
ナモグリバエ成虫

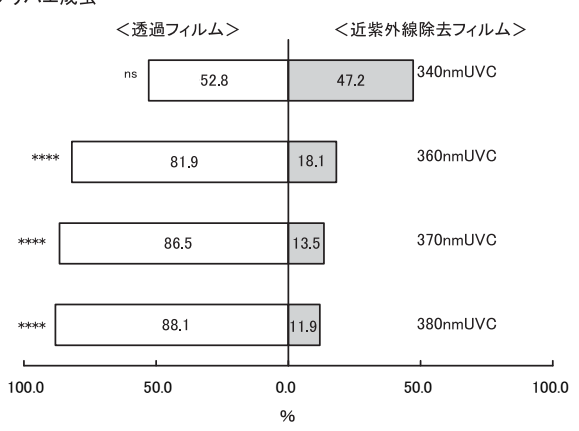

第 6 図透過波長域が異なる近紫外線除去フィルムと透過フィ ルム下でのナモグリバエ成虫の分布状況（角筒タイプ） ns $\left(p>0.05\right.$, Heterogeneity chi-square analysis $\left.{ }^{11}\right)$, $* * * *(p<0.001$, 同上 $)$

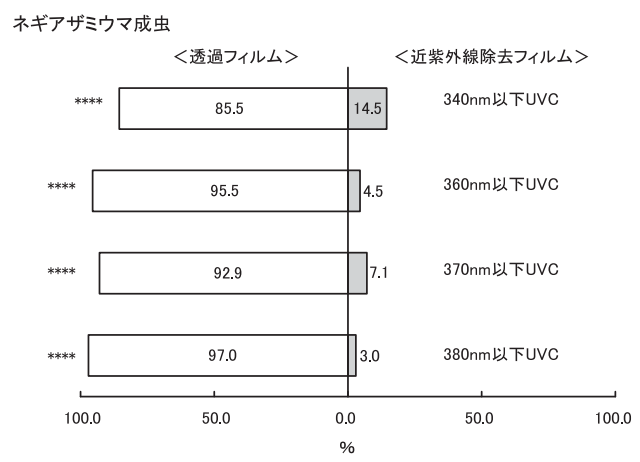

第7図透過波長域が異なる近紫外線除去フィルムと透過フィ ルム下でのネギアザミウマ成虫の分布状況（円筒タイ プ)

**** $\left(p<0.001\right.$, Heterogeneity chi-square analysis $\left.{ }^{11}\right)$
示した。カブラハバチ，キスジノミハムシ及びネギア ザミウマでは, $340 \mathrm{nmUVC}, 360 \mathrm{nmUVC}, 370 \mathrm{nmUVC}$ 及び $380 \mathrm{nmUVC}$ のすべての近紫外線除去フィルムにお いて, 当該フィルムを被覆した部分に移動した虫の数 の比率が, 透過フィルムと比較して有意に小さかった ( $p<0.001, \chi^{2}$ 検定)。コナガとナモグリバエにおいても， $360 \mathrm{nmUVC}, 370 \mathrm{nmUVC}$ 及び $380 \mathrm{nmUVC}$ フィルムを 被覆した部分に移動した虫の数の比率が, 透過フィルム と比べて有意に小さかった $\left(p<0.001, \chi^{2}\right.$ 検定 $)$ 。カブ ラハバチでは, $380 \mathrm{nmUVC}$ フィルムに移動した虫の数 の比率が1.5\%と最も小さく, 次いで $370 \mathrm{nmUVC} と 360$ nmUVC の $12.2 \%$ と 12.5\%, 340 nmUVC は30\%だった（第 3 図)。キスジノミハムシでは, $340 \mathrm{nmUVC}$ 以外の 3 種 類の近紫外線除去フィルムにおいて, 移動した虫の数の 比率が $2 \%$ 未満と極めて小さかった（第 4 図）。コナガ では, $370 \mathrm{nmUVC}$ と $380 \mathrm{nmUVC}$ が10\%前半と最も小 さく, $360 \mathrm{nmUVC}$ では27.2\%だった (第 5 図)。ナモグ リバエでは, $360 \mathrm{nmUVC}, 370 \mathrm{nmUVC}$ 及び $380 \mathrm{nmUVC}$ において20\%未満だった（第6図)。ネギアザミウマは, 360 nmUVC， 370 nmUVC 及び 380 nmUVC で10\%未満, 340 nmUVC では14.5\%だった（第7図）。

\section{考察}

本研究では, カブラハバチ, コナガ, ナモグリバエに は角筒タイプ，キスジノミハムシとネギアザミウマに円 筒タイプの実験装置を用いた（第 2 図 A, B)。実験装 置内の照度は, 角筒タイプよりも円筒タイプの方が約 $1000 \mathrm{~lx}$ 明るく, 透過フィルムや $340 \mathrm{nmUVC}$ フィルムの 被覆下では紫外線強度も異なっていた（第 1 表）。その

第 1 表 各フィルムの透過光に対する害虫の行動反応を解析するための実験装置内外の環境条件

\begin{tabular}{|c|c|c|c|c|c|}
\hline 実験装置 & 測定場所 & $\begin{array}{l}\text { 照度 }^{1)} \\
(\mathrm{Lx})\end{array}$ & $\begin{array}{c}\text { 紫外線強度 }{ }^{1)} \\
\left(\mu \mathrm{w} / \mathrm{cm}^{2}\right)\end{array}$ & $\begin{array}{l}\text { 温度 }^{1)} \\
\left({ }^{\circ} \mathrm{C}\right)\end{array}$ & $\begin{array}{c}\text { 相対湿度 }{ }^{1)} \\
(\%)\end{array}$ \\
\hline \multirow[t]{6}{*}{ 角筒タイプ } & 透過フィルムの被覆下 & 6480 & 71.4 & \multirow{5}{*}{$27.2^{2)}$} & \multirow{5}{*}{$39.3^{2)}$} \\
\hline & $340 \mathrm{nmUVC}$ フィルムの被覆下 & 6500 & 42.2 & & \\
\hline & $360 \mathrm{nmUVC}$ フィルムの被覆下 & 6430 & 14.2 & & \\
\hline & $370 \mathrm{nmUVC}$ フィルムの被覆下 & 6560 & 5.0 & & \\
\hline & $380 \mathrm{nmUVC}$ フィルムの被覆下 & 6520 & 1.1 & & \\
\hline & 外側中央（ふたの直上） & 10560 & 306.5 & 26.4 & 37.2 \\
\hline \multirow[t]{6}{*}{ 円筒タイプ } & 透過フィルムの被覆下 & 7620 & 113.0 & \multirow{5}{*}{$25.7^{2)}$} & \multirow{5}{*}{$46.5^{2)}$} \\
\hline & $340 \mathrm{nmUVC}$ フィルムの被覆下 & 7650 & 60.1 & & \\
\hline & $360 \mathrm{nmUVC}$ フィルムの被覆下 & 7560 & 13.5 & & \\
\hline & $370 \mathrm{nmUVC}$ フィルムの被覆下 & 7680 & 5.0 & & \\
\hline & 380 nmUVC フィルムの被覆下 & 7580 & 1.1 & & \\
\hline & 外側中央（黒模造紙被覆部分の直上） & 10550 & 309.4 & 26.4 & 38.3 \\
\hline
\end{tabular}

1) 平均値

2) 内部中央の暗部で測定した值 
ため, 得られた結果について害虫の種間で厳密な比較は 出来ないが，供試した害虫 5 種は，少なくとも波長 360 $\mathrm{nm}$ 以下の光を透過しない近紫外線除去フィルム下への 移動が抑制されることを示した。現在市販されている近 紫外線除去フィルムは, $380 \mathrm{~nm}$ 以下の光を透過しない ものが多い6)。したがって, 本研究で得られた結果から, 波長 $360 \mathrm{mn}$ 以下の光を透過しない近紫外線除去フィル ムにおいても, 市販の近紫外線除去フィルムと同程度の 軟弱野菜の害虫類に対する侵入抑制効果が得られる可能 性が期待できる。

永井・野中 ${ }^{8)}$, 真梶 ${ }^{9)}$, 野中・永井 ${ }^{10)}$ は, 波長 350 $\mathrm{nm}, 380 \mathrm{~nm}$ 及び $400 \mathrm{~nm}$ 以下の光を透過しない 3 種類 の近紫外線除去フィルムを被覆したビニールハウスに打 いて害虫の発生程度を比較している。永井・野中 ${ }^{8)}$ と野 中・永井 ${ }^{10)}$ は, 3 種類すべての近紫外線除去フィルム に扔いて，ミナミキイロアザミウマに対する侵入抑制効 果があったと報告している。一方，真梶ら ${ }^{9)}$ は，いずれ のフィルムもオンシツコナジラミの飛び込みは少なかっ たが，その程度は $380 \mathrm{~nm}$ 及び $400 \mathrm{~nm}$ 以下を透過しな い近紫外線除去フィルムの方がより顕著だったとしてい る。これらの 3 つの試験はすべて屋外で行われた結果で あり, 八ウスの構造や設置場所, 栽培作物, 試験時期, 天候などの影響を受けた可能性が考えられる。今回の試 験は，光質や温度等を一定に制御した環境条件下で行わ れており，近紫外線除去フィルムの種類の違いが害虫の 行動反応に与える影響を比較する上でより有用な手法 だったと考えられる。

近紫外線除去フィルムは, 病害虫の発生の他に, 天敵 や受粉昆虫の活動，作物の生育や着色などに様々な影響 を与える。本研究で軟弱野菜の害虫類に対する移動抑制 効果が確認された $360 \mathrm{nmUVC}$ フィルムのような除去波 長域のより小さな近紫外線除去フィルムについても, 害 虫以外の生物や作物に与える影響を検討する必要があ る。

\section{摘要}

透過波長域の異なる近紫外線除去フィルムが軟弱野菜 の害虫 5 種の行動に与える影響を明らかにした。カブラ ハバチ，キスジノミハムシ，ネギアザミウマは，近紫外 線を透過するフィルムと比較して, 波長 $340 \mathrm{~nm}$ 以下, $360 \mathrm{~nm}$ 以下， $370 \mathrm{~nm}$ 以下及び $380 \mathrm{~nm}$ 以下の光を透過 しない近紫外線除去フィルム下への移動が抑制された。 コナガとナモグリバエは，360 nm 以下，370 nm 以下及 び $380 \mathrm{~nm}$ 以下の光を透過しない近紫外線除去フィルム 下への移動が抑制された。これらの結果から，少なくと も波長 $360 \mathrm{mn}$ 以下の光を透過しない近紫外線除去フィ ルムでは，軟弱野菜の害虫 5 種の移動行動が抑制される 可能性が示された。

\section{引用文献}

1）井手 治 - 森山友幸・妹尾盛次 - 岡武康之 - 姫野修一 （2004）福岡県農業総合試験場研究報告 $23: 54-58$.

2) 安藤由紀子 (2006) 植物防疫 60 : 93-95.

3）柴尾 学・定 幸子・小坂吉朗・田中 寛（2004）関西病 虫研報 $46: 33-38$.

4）竹川昌宏（2004）今月の農業 48(11) : 50-53.

5）河合 章 (2000) UV 除去資材に上る害虫防除。平成12年 度課題別研究会資料 野菜・花き害虫の物理的防除法の現 状と今後の展望(野菜・茶業試験場編). 野菜・茶業試験場, 三重, pp. 26-31.

6) 高市益行（2002）紫外線カットフィルムの種類と特性. 農 業技術体系 野菜編12. 追録第27号(農山漁村文化協会編). pp. 37-38の6.

7）鹿島哲郎・松井正春（1998）茨城県農業総合センター園芸 研究所研究報告 $6: 30-36$.

8）永井清文・野中耕次（1982）植物防疫 $36: 466-468$.

9）真梶徳純・藤原孝之・天野 洋（1983）千葉大園学報 $32: 99-105$.

10）野中耕次・永井清文（1985）農業抢よび園芸 60 : 323-326.

11) Zar, J. H. (1999) Biostatistical Analysis. Fourth Edition. Prentice Hall International, London, pp. 471-473. 